\title{
Antioxidant capacity and nutritive components from biji sub-micron suspension by ultra-high pressure homogenization process
}

\author{
Seon-Ho Lee* \\ Department of Food Science and Technology, Yeungnam University, Gyeongsan 38541, Korea
}

\section{초고압균질 가공에 의해 제조된 초미세 비지 현탁액의 영양성분 및 항산화성}

\author{
이선호* \\ 영남대학교 식품공학과
}

\begin{abstract}
Biji is a tofu by-product made by squeezing the liquid out of the dregs left over from making tofu. The objectives of this research were to break the biji into sub-micron-scale particles and to prepare a biji sub-micron suspension having increased quality characteristics such as antioxidant capacity, polyphenol, dietary fiber, and soluble protein contents, in comparison with untreated biji. Disruption of biji by an ultra-high-pressure homogenization (UHPH) process was used to prepare the sub-micron suspension of biji. UHPH can be used to prepare emulsions or suspensions with extremely small particle sizes. The effect of the UHPH process on biji was studied at 1,000, 1,500, and 2,000 bar. The extraction yield increased up to $\mathbf{1 . 6 4}$ times by breaking the biji to form a sub-micron suspension. The soluble dietary fiber, protein, and free amino acid contents were increased by the UHPH process $(p<0.05)$, in comparison with those of untreated biji. Furthermore, the total sugar, free sugar, and total polyphenol contents of biji were augmented by the UHPH process. Antioxidant activity (ABTS) after exposure to UHPH (1,000-2,000 bar) was well retained $(p<0.05)$. The extraction efficiencies and nutritive components were enhanced by increasing the pressure in the UHPH process.
\end{abstract}

Key words : biji, soybean, high pressure homogenization, extraction yield

\section{서 론}

대두는 단백질이 풍부하고 영양적으로 우수한 식품으로 알려져 있으며, 생체 대사에 필요한 각종 생리활성 물질들 을 함유하고 있어 건강식품 소재로도 다양하게 이용되고 있다. 국내에서 소비되는 대두는 생두로 일부 사용되고, 대부분이 가공식품 즉 대두식용유, 두부 및 두유 등의 형태 로 유통되고 있다(1). 두부는 콩을 마쇄하여 끓이고 콩 속의 가용성 단백질을 추출한 후 압착하고 응고시켜 만든 식품이 다. 압착 가공 공정에서 여과된 액체를 두유라고 하며 여과

*Corresponding author. E-mail : lotte@yu.ac.kr, Phone : 82-53-795-5350, Fax : 82-53-810-4662

Received 14 September 2015; Revised 2 October 2015; Accepted 3 October 2015.

Copyright (c) The Korean Society of Food Preservation. All rights reserved.
되지 않은 찌꺼기를 비지라고 한다. 비지는 함황 아미노산 과 lysine의 함량이 높고, 양질의 단백질과 풍부한 섬유소 및 다양한 대두 유래의 영양성분을 포함한다(2-4). 콩 비지 는 단백질 섭취량에 따른 체중 증가량의 비율을 나타내는 값인 단백질 효율비(protein efficiency ratio, PER)가 대두, 두유 및 두부 중에서 가장 높은 우수한 단백질 자원이다(5) 두류 가공공정의 부산물인 비지는 가축사료로 사용되기도 하지만 수분함량이 높아 건조하는 비용이 많이 들고, 부패 및 변질이 쉬워 보관의 어려움이 있다. 이 때문에 많은 양의 비지가 폐기 처리되고 있어 식량 자원의 낭비뿐만 아니라 환경오염도 초래하고 있다(1). 비지에 대한 연구로는 식품 첨가물로 활용(1), 식이섬유와 단백질분리(4), 비지 건조 $(6,7)$, 비지 koji 첨가 간장(8), 비지 홍국색소(9)에 관한 연구 등이 있다.

초고압 균질(ultra high pressure homogenization, UHPH) 가공 기술은 물리적인 힘으로 식품의 입도를 감소시켜 물질 
의 고유한 성질을 변화시키는 top down 방식의 나노 분쇄기 술이다. 나노 기술은 생활전반에 걸쳐 사용되고 있으며 나 노 분쇄 기술을 식품에 활용하게 되면 단백질, 영양성분 및 항산화제 등을 체내에 효과적으로 전달할 수 있어 기능 이 향상된 가공식품제조가 가능하다. 초고압균질 가공 방 법은 세포 구조를 파괴하고 세포내 물질을 작은 입자상으로 만들어 항산화물질 등의 용출을 증대시키고 항산화성을 향상시킨다(10-12). 초고압균질 가공기술은 종래의 균질화 와 원리는 같지만 매우 높은 압력을 주어 식품 입자를 초미 세 사이즈로 만들어 안정된 에멀젼 또는 분산액을 만들 수 있다. 이 방법은 샐러드 드레싱, 시럽, 음료, 초콜릿 등의 제조에 사용되고 있으며, 초고압균질 처리 과정에서 생성 되는 공동현상(cavitation), 충격력 및 전단력 등의 물리적인 힘이 원료에 가해져 식품입자를 매우 미세한 나노 입자로 분쇄하여 준다 $(10,11)$.

초고압 균질 기술을 활용한 연구로는 사과주스의 항산화 성 등에 미치는 영향(11), 고구마 잎 flavonoid의 항산화성 (12), 스피루나로부터 단백질 분리(13), 클로렐라 초미세 현탁액 제조(14), 토마토와 당근 퓨레의 항산화성 등에 미치 는 영향(15), 밀기울의 이화학적 특성(16)에 관한 연구들이 수행되었다.

본 연구는 식품 폐기물인 비지를 활용하여 가공식품을 개발하기 위한 일환으로 수행되었다. 즉 비지를 죽, 음료 및 유동식 등으로 가공하기 위해 초고압균질 가공 기술을 활용하여 초미세비지 현탁액을 제조하고 추출수율, 영양성 분 및 항산화성을 확인하였다.

\section{재료 및 방법}

\section{비지 제조}

본 실험에 사용한 콩은 정선농협으로부터 2008년산 백태 (Glycine $\max$ L. Merrill)를 구입하여 사용하였다. 정선된 콩을 실온에서 12시간 수침한 후 체 $(60 \mathrm{mesh})$ 로 걸러 물기 를 제거하고 콩 중량의 10 배인 증류수와 함께 마쇄하여 두미를 제조하였다. 두미를 $95^{\circ} \mathrm{C}$ 에서 10 분간 가열하였으며 가열한 두미는 여과포에 걸러 두유를 압출하였다. 두유제 조 부산물로 생성된 콩비지는 $-20^{\circ} \mathrm{C}$ 에서 보관하며 실험 재 료로 사용하였다. 비지의 수분, 조단백, 조회분, 탄수화물 함량은 AACC 방법(17)에 의해 측정하였으며, 조지방은 $\mathrm{AOAC}$ Soxhlet 방법(18)에 의해 측정하였다.

\section{초미세 비지 현탁액 제조 및 가용성분 추출수율 측정}

초미세 비지 현탁액 제조 전 비지의 수분함량이 $10 \%$ 이하가 되도록 $60^{\circ} \mathrm{C}$ 에서 열풍 건조하였다. 건조 비지 무게 에 대하여 10 배의 증류수를 가하여 30 분간 분산시키고 homogenizer(PH 91, SMT Co., Tokyo, Japan)를 이용하여
$10,000 \mathrm{rpm}$ 으로 5 분간 1 차 분쇄를 실시하였다. 초고압 균질 기(MN250, Micronox Co., Seongnam, Korea)의 압력을 $1,000 \mathrm{bar}, 1,500 \mathrm{bar}$ 및 2,000 bar로 설정하여 비지 분산액을 통과시켜 초미세 비지 현탁액을 제조하였다. 초미세 비지 현탁액의 가용성분 추출수율 결정 및 성분 분석을 위해 현탁액을 동결건조한 후 분쇄기를 이용하여 분쇄하고 35 mesh 체로 분말화 하였다. 제조된 분말에 10 배의 증류수를 가하고 $95^{\circ} \mathrm{C}$ 에서 12 시간 동안 추출하였다. 시료추출 후 가 용화 성분에 따른 추출수율 측정은 추출물을 건조시켜 건물 중량을 구한 다음 추출에 사용한 원료 건물량에 대한 백분 율로 계산하였다. 대조군으로는 건조비지를 초고압균질 공 정은 제외하고 나머지는 같은 조건으로 추출하였다.

\section{식이섬유함량 분석}

수용성 및 불용성 식이섬유 함량은 Prosky 등의 방법(19) 에 따라 식이섬유 분석 kit(Sigma-Aldrich Co., St. Louis, $\mathrm{MO}, \mathrm{USA}$ )를 사용하여 측정하였다. 건조 시료 $1 \mathrm{~g}$ 에 $\mathrm{MES} / \mathrm{TRIS}$ buffer를 $40 \mathrm{~mL}$ 첨가하고, a-amylase(SigmaAldrich Co., A 3306) $50 \mu \mathrm{L}$ 를 첨가하여 수욕조에서 $97^{\circ} \mathrm{C}$ 에 서 25 분간 반응시켰다. $97^{\circ} \mathrm{C}$ 반응 후 $60^{\circ} \mathrm{C}$ 의 수옥조에서 protease(Sigma-Aldrich Co., P 3910) 용액 $100 \mu \mathrm{L}$ 를 가하여 30 분간 반응시켰다. $0.56 \mathrm{~N} \mathrm{HCL} 5 \mathrm{~mL}$ 를 가하고 $1 \mathrm{~N} \mathrm{HCl}$ 과 $6 \mathrm{~N} \mathrm{NaOH}$ 를 이용하여 $\mathrm{pH}$ 를 4.45 4.55 범위로 조정한 후 amyloglucosidase(Sigma-Aldrich Co., A 9913) $100 \mu \mathrm{L}$ 를 첨 가하였다. $60^{\circ} \mathrm{C}$ 에서 30 분간 반응시킨 후, $60^{\circ} \mathrm{C}$ 의 $95 \%$ ethanol $190 \mathrm{~mL}$ 를 가하고 $60^{\circ} \mathrm{C}$ 에서 1 시간 진탕한 후 실온에 서 방냉하였다. 항량을 구해놓은 glass filter에 효소분해 한 sample을 여과하고 $78 \%$ ethanol, $95 \%$ ethanol, acetone의 순서로 각 40 50 mL 사용하여 세척하였다. glass filter는 $105^{\circ} \mathrm{C}$ oven에 overnight 후 1 시간 방냉하여 잔사량을 구하 였다.

\section{환원당 및 총당 함량 측정}

총당 함량은 Dubois 등의 방법(20)을 변형하여 측정하였 다. 즉 시료 $500 \mu \mathrm{L}, 5 \%$ phenol $500 \mu \mathrm{L}$, 진한 황산 $2.5 \mathrm{~mL}$ 를 잘 섞은 후 끓는 물에 10 분간 반응시켰다. 15 분간 얼음물에 식히고 $490 \mathrm{~nm}$ 에서 흡광도를 측정하였으며 표준품은 sucrose를 사용하였다. 환원당 측정은 dinitrosalicylic acid(DNS) 법(21)을 응용하여 측정하였다. 시험관에 시료 $1 \mathrm{~mL}, \mathrm{DNS}$ 시약 $3 \mathrm{~mL}$ 와 $40 \%$ potassium sodium tartrate solution $1 \mathrm{~mL}$ 를 첨가하고 끓는 물에 5 분간 반응을 시켜 냉수에서 급 냉각시 킨 후 $575 \mathrm{~nm}$ 에서 흡광도를 측정하였다.

\section{가용성 단백질 및 유리아미노산 함량 측정}

가용성 단백질 함량은 Lowry의 방법(22)에 따라 측정하 였다. 시료 $100 \mu \mathrm{L}$ 에 Lowry 시약을 첨가하여 발색시킨 후, 분광광도계(UV-1800, Shimazu, Kyoto, Japan)를 사용하여 
$750 \mathrm{~nm}$ 에서 흡광도를 측정하였다. Bovine serum albumin (Sigma-Aldrich Co., A-7030)을 표준품으로 사용하여 표준 곡선을 작성하고 시료 중의 단백질함량을 계산하였다. 유 리아미노산 측정은 Folin과 Denis의 방법(23)을 변형하여 사용하였다. 시료 $100 \mu \mathrm{L}$ 와 $0.55 \mathrm{M} \mathrm{Na}_{2} \mathrm{CO}_{3}$ 용액 $1 \mathrm{~mL}$ 를 가하고 Folin-Ciocalteau reagent 반응시약과 $30^{\circ} \mathrm{C}$ 에서 30 분 간 반응을 시킨 후 $750 \mathrm{~nm}$ 에서 흡광도를 측정하였다.

\section{유리당 및 올리고당 분석}

유리당 함량은 $45^{\circ} \mathrm{C}$ 에서 HPLC(LC-20A, Shimadzu, Kyoto, Japan)로 분석하였다. Column은 Shodex Aahipak NH2P-50 4E(4.6×250 mm, i.d., Shodex, Tokyo, Japan)을 이 용하였다. 분석조건은 이동상 용매 $75 \%$ acetonitrile, 유속 $1 \mathrm{~mL} / \mathrm{min}$ 이었다. 올리고당 함량은 HPLC로 분석하였으며 칼럼은 Shodex KS-801(300 $\times 8.0 \mathrm{~mm}$, i.d., Shodex $)$ 을 사용하 였다. 시료 주입량은 $10 \mu \mathrm{L}, \mathrm{RI}$ detector(Shimadzu RID-10A) 를 이용하였고 유속 $0.7 \mathrm{~mL} / \mathrm{min}$, 이동상 용매는 water, 측정 온도는 $80^{\circ} \mathrm{C}$ 였다.

\section{이소플라본 함량 분석}

시료를 $0.22 \mu \mathrm{m}$ syringe filter로 여과한 후 HPLC(LC-20A, Shimadzu)로 분석하였다. 분석에 사용된 칼럼은 ACE5 $\mathrm{C}_{18}(250 \times 4.6 \mathrm{~mm}$ i.d., Advanced Chromatography Technologies, Aberdeen, Scotland)이었다. 시료 주입량은 $10 \mu \mathrm{L}$ 였으며, UV detector(Shimadzu SPD-20A)로 $254 \mathrm{~nm}$ 에서 $1 \mathrm{~mL} / \mathrm{min}$ 의 유속으로 분석하였다. 이동상 용매의 gradient는 용매 $\mathrm{A}$ (water) : 용매 $\mathrm{B}$ (acetonitrile) $=85: 15$ 로 시작하여 35 분 후 55:45로 흘리고 5 분 후 85:25로 변경하였다. 이소플라본 함량은 표준물질 4가지(genistein, genistin, daidzein, daidzin) 의 농도에 대한 peak 면적의 표준정량곡선으로부터 계산하 였다.

\section{총 폴리페놀 함량 측정}

총 폴리페놀 함량은 Gutfiger의 방법(24)에 따라 FolinCiocalteu reagent가 추출물의 폴리페놀성 화합물에 의해 환원된 결과 몰리브덴 정색으로 발색하는 원리를 응용하여 측정하였다. 시료 $0.1 \mathrm{~mL}$ 에 $2 \mathrm{~N}$ Folin-Ciocalteu reagent 0.1 $\mathrm{mL}$ 를 가하여 5 분간 상온에서 반응시킨 후 $0.7 \mathrm{M} \mathrm{Na}_{2} \mathrm{CO}_{3}$ $1 \mathrm{~mL}$ 을 가하고 실온에서 1시간 동안 반응시키고 $725 \mathrm{~nm}$ 에 서 흡광도를 측정하였다. 표준물질은 tannic acid를 사용하 였다.

\section{$\mathrm{DPPH}$ 및 $\mathrm{ABTS}$ 라디칼 소거 활성 측정}

$\mathrm{DPPH}$ 라디칼 소거능은 Blois의 방법(25)을 변형한 1,1-diphenyl-2-picryl hydrazyl(DPPH, Sigma-Aldrich Co.) 전자공여능을 측정하였다. 시료 $100 \mu \mathrm{L}$ 에 $0.2 \mathrm{mM} \mathrm{DPPH}$ 용액 $50 \mu \mathrm{L}$ 를 가하여 10 분간 반응시킨 후 $517 \mathrm{~nm}$ 에서 흡광
도를 측정하였다. $\mathrm{DPPH}$ 항산화능은 시료용액 첨가구와 무 첨가구의 흡광도 감소율로 계산하였고 $\mathrm{DPPH}$ 항산화 활성이 $50 \%$ 감소하는데 필요한 시료의 농도인 $\mathrm{RC}_{50}$ 값으로 나타내었다. 총 항산화력은 Blois의 방법(25)을 변형하여 측정하였다. 즉 $7 \mathrm{mM} \mathrm{ABTS}$ 와 $2.45 \mathrm{mM}$ potassium persulfate 용액을 혼합하여 하루 동안 암소에 방치하여 $\mathrm{ABTS}^{+}$라디칼 을 형성시킨 후 $734 \mathrm{~nm}$ 에서 0.7 0.9가 되도록, 몰 흡광계수 를 이용하여 증류수로 희석하였다. 추출물 $50 \mu \mathrm{L}$ 에 희석된 $\mathrm{ABTS}^{+}$라디칼 용액 $100 \mu \mathrm{L}$ 를 가하고 5 분후 흡광도의 변화 를 측정하였다. $\mathrm{ABTS}$ 의 항산화능은 시료용액의 첨가구와 무 첨가구의 흡광도 감소율로 계산하였고, $\mathrm{ABTS}$ 항산화 활성이 $50 \%$ 감소하는데 필요한 시료의 농도인 $\mathrm{RC}_{50}$ 값으로 나타내었다.

\section{통계처리}

실험을 통하여 얻어진 결과는 SPSS program(18.0, SPSS Inc., Chicago, IL, USA)을 이용하여 평균표준편차로 나타 내었고, 실험군 간의 평균값의 통계적 유의성은 $\mathrm{p}<0.05$ 수 준에서 Duncan's multiple range test에 의해 검정하였다.

\section{결과 및 고찰}

\section{비지의 일반성분}

초미세 비지 현탁액 제조에 사용된 건조 비지의 일반성 분 분석 결과 수분 $3.71 \pm 0.16 \%$, 조단백 $15.20 \pm 0.21 \%$, 조지 방 $5.35 \pm 0.24 \%$, 조회분 $2.51 \pm 0.12 \%$ 였다(data not shown). Woo 등(1)은 비지는 조단백질 $37.3 \%$, 조지방 $17.9 \%$ 회분 $4.2 \%$, 탄수화물 $40.6 \%$ 를 함유하고 있다고 보고하였고, Lee 등(26)의 연구에서는 수분 $87.77 \%$, 단백질 $3.48 \%$, 조지방 $2.43 \%$, 회분 $0.52 \%$, 탄수화물 $5.80 \%$ 이었다고 보고하였다. 한편 $\operatorname{Im}$ 등(27)이 보고한 비지의 일반성분은 수분 $86.73 \%$, 조단백 $3.47 \%$, 조지방 $0.99 \%$, 조섬유 $0.03 \%$ 및 조회분 $0.23 \%$ 이었다. 각 실험에서의 일반 성분 분석결과가 차이가 있는데 이는 공장 또는 가정마다 두유 또는 두부 제조하는 방법과 비지 회수 공정에서 차이가 있으며 원료 백태 품종 간에도 일반성분의 차이가 있기 때문으로 판단되었다(27). 본 실험에 사용한 비지는 건조된 비지였으나 Lee 등(26)이 나 $\operatorname{Im}$ 등(27)의 연구에서 사용한 비지는 수분 함량이 $87.77 \%, 86.73 \%$ 로 수분함량이 매우 높은 건조되지 않은 비지로, 원료 비지의 보관 상태도 일반성분 함량이 차이가 나는 원인이었다.

\section{추출수율}

초고압 균질 가공처리 비지의 각 추출공정에 따른 추출 물의 수율은 Fig. 1에 나타내었다. 대조군의 열수 추출물의 수율은 $12.37 \%$ 였으며 $1,000 \mathrm{bar}, 1,500 \mathrm{bar}$ 및 2,000 bar 고압 
처리군의 수율은 각각 $19.42 \%, 20.35 \%$ 및 $19.42 \%$ 로 대조구 에 비해 수율이 1.56 1.64배 증가하였으며 전 실험구에서 모두 추출 수율이 유의적으로 증가하였다(p<0.05). Yu (14) 는 초고압균질 공정을 사용하여 클로렐라 현탁액을 제조했 을 때 처리전과 비교하여 최대 6 배 이상의 루테인을 얻었으 며, 제조된 초미세 현탁액을 모델 음료에 적용하여 저장기 간 동안 안정함을 확인한 바 있다. 고로쇠에 초고압을 가하 여 추출할 경우에는 열수 추출보다 약 1.5 배의 수율이 증가 했다고 보고되었다(28). 약재를 포함한 식재료로 부터 유용 성분을 추출할 때 전통적으로 사용해온 방법은 물과 재료를 넣고 끓여서 뜨꺼운 물로 추출하는 열수 추출 방법이다. 열수 추출법을 이용하여 추출할 경우 높은 추출 온도로 인해 재료에 함유된 단백질이나 비타민 등이 손실되거나 변성되기도 하며 물에 녹을 수 있는 가용성 성분 위주로만 추출되므로 추출수율이 높지 않은 편이다. 초고압 균질 가 공처리한 비지의 경우 가공 중 가해진 초고압으로 인해 세포벽이 파괴되고 입자가 더욱 미세한 상태가 되어 가용성 성분이 증가하여 추출 수율 증진에 기여한 것으로 사료된다 $(29,30)$.

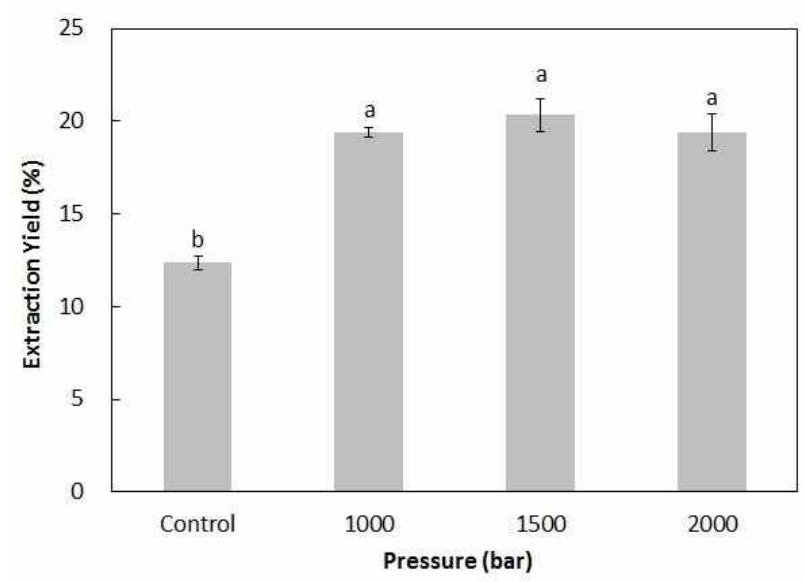

Fig. 1. Extraction yield of the biji sub-micron suspension by ultra-high-pressure homogenizer at different pressures.

Values are mean $\pm \mathrm{SD}(\mathrm{n}=3)$. Means in the bars with different letters are significantly different at $p<0.05$ by Duncan's multiple range test.

\section{식이섬유 함량}

초고압 균질 가공 처리된 식이 섬유 함량은 Table 1 에 나타내었다. 대조구의 가용성 식이섬유 함량은 $24.13 \mathrm{mg} / \mathrm{g}$ 이었으며, 압력을 $1,000 \mathrm{bar}, 1,500 \mathrm{bar}, 2,000 \mathrm{bar}$ 로 증가시킴 에 따라 실험구의 가용성 식이섬유함량은 $36.90 \mathrm{mg} / \mathrm{g}, 54.59$ $\mathrm{mg} / \mathrm{g}$ 및 $67 \mathrm{mg} / \mathrm{g}$ 으로 유의적을 증가하였다(p<0.05). 불용성 식이섬유의 함량은 초고압균질 처리구가 대조구에 비해 유의적으로 감소하였다 $(\mathrm{p}<0.05)$. 일반 추출법으로는 비지 의 식이섬유를 추출하는데 한계가 있으나 초고압균질 가공 처리로 충격력, 전단력 등의 물리적 힘이 작용하여 불용성 식이섬유 입자가 파괴되어 불용성 식이섬유의 함량이 유의
적 $(\mathrm{p}<0.05)$ 으로 감소하고 가용성 식이섬유의 함량이 증가 한 것으로 판단되었다. Chou 등(31)은 초고압균질 처리로 당근의 불용성 식이섬유의 입자 크기가 줄어들고 콜레스테 롤 억제효과가 있었다고 보고 한바 있다. 비지를 고압균질 처리로 초미세화하면 식이섬유소의 기능을 향상시킬 수 있으며 유지와 수분 보유력이 우수하고 지질 흡수를 저해하 는 기능성 소재로서 활용할 수 있다(16)는 보고를 근거했을 때 고압균질 가공처리에 의해 비지에 함유된 식이섬유소의 기능을 향상시킬 수 있을 것으로 사료된다

Table 1. Dietary fiber, reducing sugar, total sugar, soluble protein, and free amino acid contents of the biji sub-micron suspension obtained by ultra-high-pressure homogenization at different pressures

$(\mathrm{mg} / \mathrm{g})$

\begin{tabular}{lcccc}
\hline & \multicolumn{4}{c}{ Pressure (bar) } \\
\cline { 2 - 5 } & Control & 1,000 & 1,500 & 2,000 \\
\hline Soluble dietary fiber & $24.13 \pm 0.91^{\mathrm{d} 1)}$ & $36.90 \pm 2.46^{\mathrm{c}}$ & $54.50 \pm 1.47^{\mathrm{b}}$ & $67.00 \pm 2.40^{\mathrm{a}}$ \\
Insoluble dietary fiber & $584.03 \pm 11.96^{\mathrm{a}}$ & $548.03 \pm 7.26^{\mathrm{b}}$ & $547.33 \pm 14.32^{\mathrm{b}}$ & $556.00 \pm 12.08^{\mathrm{b}}$ \\
Reducing sugar & $13.48 \pm 0.74^{\mathrm{d}}$ & $41.95 \pm 0.83^{\mathrm{c}}$ & $72.68 \pm 2.22^{\mathrm{b}}$ & $127.03 \pm 4.67^{\mathrm{a}}$ \\
Total sugar & $247.92 \pm 2.03^{\mathrm{d}}$ & $293.76 \pm 5.85^{\mathrm{c}}$ & $348.07 \pm 2.35^{\mathrm{b}}$ & $415.96 \pm 5.55^{\mathrm{a}}$ \\
Soluble protein & $114.88 \pm 2.37^{\mathrm{c}}$ & $116.31 \pm 1.25^{\mathrm{c}}$ & $128.29 \pm 1.15^{\mathrm{a}}$ & $124.63 \pm 0.53^{\mathrm{b}}$ \\
Free amino acid & $7.39 \pm 0.22^{\mathrm{c}}$ & $12.58 \pm 0.05^{\mathrm{a}}$ & $11.36 \pm 0.86^{\mathrm{b}}$ & $10.65 \pm 2.10^{\mathrm{b}}$ \\
\hline
\end{tabular}

${ }^{1)}$ Values are mean $\pm \mathrm{SD}(\mathrm{n}=3)$. Means with different superscripts in the same raw are significantly different $(\mathrm{p}<0.05)$ by Duncan's multiple range test.

\section{단백질 함량 및 유리아미노산}

가용성 단백질 함량은 Table 1 에 나타내었다. 가용성 단 백질의 함량은 대조구에 비해 $1,000 \mathrm{bar}$ 의 압력에서는 유의 적인 차이가 없었으나, $1,500 \mathrm{bar}$ 와 2,000 bar의 압력을 가했 을 때는 유의적으로 증가하였다( $\mathrm{p}<0.05)$. 유리 아미노산의 함량은 전 실험구에서 대조구에 비해 유의적으로 증가하였 다(p<0.05). Lei 등(13)은 고압균질 처리 기술을 이용하여 spirulina cell을 분쇄하여 총단백질의 함량을 $74 \%$ 까지 얻었 다고 보고한 바 있다. 압력에 따라 단백질이 변성되고, 단백 질 분자의 이온결합 또는 소수성 결합이 분해되어 단백질의 분자구조가 풀어져 가용성 단백질 함량과 유리아미노산 함량이 증가된 것(32,33)으로 보인다.

\section{총 당 함량 및 환원당 함량}

총 당 함량은 대조구가 $247.92 \mathrm{mg} / \mathrm{g}$ 이었으며, 모든 실험 구에서 처리 압력이 증가함에 따라 총당 함량도 유의적으로 증가하였다(p<0.05). $2,000 \mathrm{bar}$ 의 압력을 가했을 때 총 당 함량은 $415.96 \mathrm{mg} / \mathrm{g}$ 까지 증가하였다. 초고압균질 가공처리 한 비지는 전 실험구에서 환원당의 함량도 대조구에 비해 처리 압력이 증가할수록 유의적으로 증가함을 나타내었다 $(\mathrm{p}<0.05) .2,000 \mathrm{bar}$ 의 압력을 가한 비지의 경우 총당 및 환원당 모두 가장 높은 함량을 나타내어 고압균질 가공처리 
를 할수록 당 함량이 증가됨을 확인하였다. 이는 비환원당 이 고압균질 가공 처리에 의하여 환원당으로 가수 분해되어 환원당 함량이 증가한 것으로 추정된다. 초고압 가공처리 에 의하여 비지의 내부 공기가 빠지고 물리적인 힘이 작용 하여 식품입자가 매우 미세하게 분쇄되고 딱딱한 불용성 구조가 붕괴되며, 용매와 접촉하는 표면적이 넓어져 다당 류가 많이 추출되어 총 당 함량도 증가 한 것으로 사료된다.

\section{유리당 및 올리고당 함량 분석}

비지에 함유된 유리당과 올리고당의 함량을 HPLC를 이 용하여 분석하였으며 결과는 Table 2에 나타내었다. 유리당 과 올리고당을 포함해서 대조구에 가장 많이 함유된 당은 stachyose였고 함량은 $8.03 \mu \mathrm{gg} / \mathrm{g}$ 이었다. 고압균질 처리한 비지에 함유된 당은 $2,000 \mathrm{bar}$ 의 압력을 처리했을 때 raffinose의 함량이 가장 높았다. Raffinose는 대조구에 비해 압력을 높게 가할수록 함량이 높아지는 경향을 보였다.

\section{이소플라본과 총 폴리페놀 함량 분석}

대조구 비지와 고압균질 가공 처리 비지의 이소플라본 함량을 측정하여 비교한 결과는 Table 3 에 나타내었다. 이 소플라본 함량은 고압 균질 가공 처리 시 daidzin과 genistin 함량이 유의적을 증가하였다 $(\mathrm{p}<0.05)$. 대조구의 daidzin과 genistin의 함량은 각각 $8.32 \mathrm{mg} \%$ 와 $2.08 \mathrm{mg} \%$ 였으며 2,000 bar로 고압균질 처리 실험구의 경우 각각 $13.68 \mathrm{mg} \%$ 와 $10.34 \mathrm{mg} \%$ 로 증가하여 가압처리에 의해 유의적을 증가하 는 경향을 보였다( $\mathrm{p}<0.05)$. 대조구에 비해 daidzein과 genistein 함량은 고압균질 처리 실험구 모두에서 유의적으 로 낮은 값을 나타내었다(p<0.05). 대조구의 daidzein과 genistein의 함량에 비해 고압균질 가공 처리한 실험구의 함량이 감소하였다(p<0.05). $\operatorname{Im}$ 등(27)은 끓는 물에서 마쇄 하는 단계에서 isoflavone의 손실이 많이 일어난다고 하였 으며, 대두 제품에서 수침, 가열, 마쇄, 가열처리, 효소적 가수분해, 발효에 의해 isoflavones 성분이 유의적으로 변화 한다고 보고한 바 있다.

총 폴리페놀 함량 측정 결과 고압균질 가공 처리한 비지 에서 모두 높은 함량을 나타내었고 특히 $1,500 \mathrm{bar}$ 와 2,000 bar로 고압균질 처리하였을 경우는 유의적으로 총 페놀 함 량이 증가하였다 $(\mathrm{p}<0.05)$. 고압균질 처리한 고구마 잎을 scanning electron microscope(SEM)를 이용하여 관찰했을 때 압력을 증가시킬수록 세포구조가 파괴되고 세포내 물질 들이 작은 입자상으로 부서져 표면적이 향상되었으며, 용 매의 침투성을 향상시켜 항산화 물질의 용출을 증가시켰다 는 보고(12)와 사과주스를 고압균질 가공했을 때 총 페놀 함량이 증가하였으며 항산화성도 향상되었다는 보고(16) 에 근거할 때 초고압균질 가공 처리한 비지도 항산화성이 향상될 것으로 예상되었다.

Table 2. Free sugar and oligo-saccharide contents of the biji sub-micron suspension obtained by ultra-high-pressure homogenization at different pressures

\begin{tabular}{cccccccc}
\hline \multirow{2}{*}{ Pressure (bar) } & \multicolumn{9}{c}{ Contents of carbohydrate $(\mu \mathrm{g} / \mathrm{g})$} \\
\cline { 2 - 7 } & Fructose & Glucose & Sucrose & Glactose & Stachyose & Raffinose \\
\hline Control & $1.41^{1)}$ & 3.23 & $\mathrm{ND}^{2)}$ & $\mathrm{ND}$ & 8.03 & 1.17 \\
1,000 & 2.82 & 1.56 & 3.85 & $\mathrm{ND}$ & 8.14 & 4.54 \\
1,500 & 4.45 & $\mathrm{ND}$ & 3.21 & $\mathrm{ND}$ & 9.23 & 9.68 \\
2,000 & 3.69 & $\mathrm{ND}$ & $\mathrm{ND}$ & 0.56 & 8.04 & 9.56 \\
\hline
\end{tabular}

${ }^{1)}$ Values are mean $(\mathrm{n}=3)$.

${ }^{2)} \mathrm{ND}$, not detected.

Table 3. Isoflavone and total phenolic compound contents of the biji sub-micron suspension obtained by ultra-high-pressure homogenization at different pressures

$(\mathrm{mg} \%)$

\begin{tabular}{|c|c|c|c|c|c|}
\hline \multirow{3}{*}{ Pressure (bar) } & \multicolumn{4}{|c|}{ Contents of isoflavone } & \multirow{3}{*}{ Total phenolic compound } \\
\hline & \multicolumn{2}{|c|}{ Glycoside type } & \multicolumn{2}{|c|}{ Aglycone type } & \\
\hline & Daidzin & Genistin & Daidzein & Genistein & \\
\hline Control & $8.32 \pm 0.71^{\mathrm{bl})}$ & $2.08 \pm 0.20^{b}$ & $3.33 \pm 0.28^{\mathrm{a}}$ & $2.27 \pm 0.16^{\mathrm{a}}$ & $249.33 \pm 17.90^{c}$ \\
\hline 1,000 & $13.32 \pm 0.33^{\mathrm{a}}$ & $9.79 \pm 0.51^{\mathrm{a}}$ & $0.50 \pm 0.03^{\mathrm{c}}$ & $0.49 \pm 0.02^{b}$ & $272.33 \pm 2.89^{c}$ \\
\hline 1,500 & $13.62 \pm 0.51^{a}$ & $10.21 \pm 0.64^{\mathrm{a}}$ & $0.51 \pm 0.11^{c}$ & $\mathrm{ND}^{2)}$ & $467.67 \pm 21.55^{\mathrm{b}}$ \\
\hline 2,000 & $13.68 \pm 1.53^{\mathrm{a}}$ & $10.34 \pm 0.83^{\mathrm{a}}$ & $0.82 \pm 0.02^{\mathrm{b}}$ & $0.82 \pm 0.90^{b}$ & $513.67 \pm 1.53^{\mathrm{a}}$ \\
\hline
\end{tabular}

\footnotetext{
${ }^{1)}$ Values are mean $\pm \mathrm{SD}(\mathrm{n}=3)$. Means with different superscripts in the same raw are significantly different $(\mathrm{p}<0.05)$ by Duncan's multiple range test.

${ }^{2)} \mathrm{ND}$, not detected.
} 


\section{전자공여능(DPPH) 및 $\mathrm{ABTS}$ 라디칼 소거 활성}

$\mathrm{DPPH}$ 를 이용하여 비지 및 초고압균질 가공처리 비지의 전자 공여능 효과를 Fig. 2에 나타내었다. $6000 \mathrm{\mu g} / \mathrm{mL}$ 에서 $1,000 \mathrm{bar}$ 의 압력을 가한 비지가 $11.86 \%$ 로 가장 높은 DPPH 라디칼 소거능을 보였으나 $1,500 \mathrm{bar}$ 및 $200 \mathrm{bar}$ 처리 실험구 에서는 대조구와 비교하여 유의적인 변화가 없었다 $(\mathrm{p}<0.05)$.

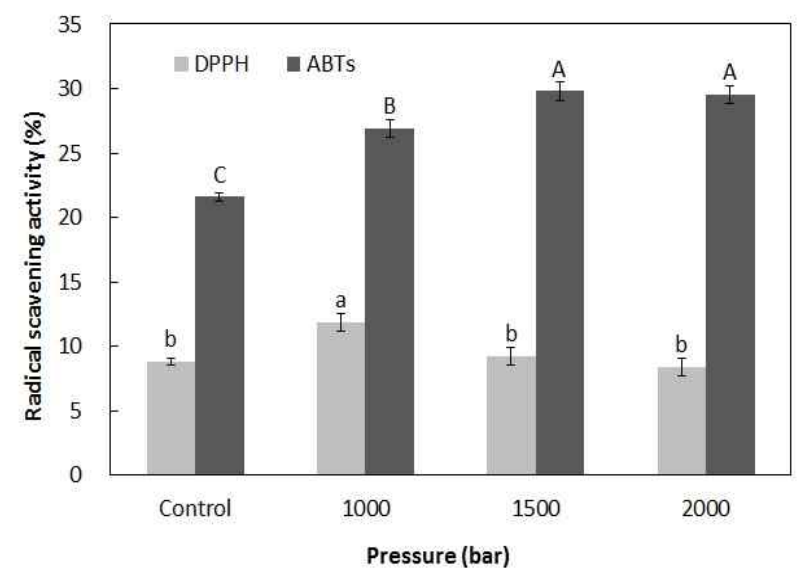

Fig. 2. DPPH radical and ABTS radical scavenging activities of the biji sub-micron suspension by ultra-high-pressure homogenization at different pressures.

Concentration of sample was $6,000 \mu \mathrm{g} / \mathrm{mL}$. Values are mean \pm SD $(\mathrm{n}=3)$. Means with different letters above the bars are significantly different $(p<0.05)$ by Duncan's multiple range test.

$\mathrm{ABTS}$ 라디칼 소거능은 고압균질 공정을 거친 실험구가 대조구보다 모두 유의적으로 높은 라디컬 소거능을 나타내 었다(p<0.05). 이는 녹차를 미쇄 분말화 했을 때 일반 녹차 분말보다 100배 이상 항산화 효과를 나타내었으며(10), 고 압처리 기술은 고구마 잎의 항산화 물질의 용출을 증대시키 고 항산화성을 향상시킨다(12)는 보고와 일치하였다. 본 실험의 결과 $\mathrm{DPPH}$ 를 이용한 항산화성 실험은 대조구와 실험구간에 큰 차이가 없었으며 ABTS 라디컬 소거능은 실험구가 유의적으로 높은 경향을 보였다. 사과 주스를 고 압균질 처리했을 때 $\mathrm{DPPH}$ 를 이용한 항산화성 실험 결과는 유의적 차이가 없었고 trolox equivalent antioxidant capacity (TEAC)와 oxygen radical antioxidant capacity(ORAC) 측정 결과는 유의적인 차이가 있었다(16)고 보고된 바 있다. 고압 균질 가공 처리에 의해 비지 분말이 미세화되고 총 페놀 함량과 항산화성도 향상된 것으로 판단된다.

이상의 결과에서 초고압 균질 가공 기술을 활용하여 비 지를 초미세화 시키면 영양성분의 추출 효율이 높아지고 항산화성이 향상됨을 확인하였으며, 초미세 사이즈로 가공 된 비지 현탁액을 죽, 음료, 다이어트 식품 및 유동식 등으로 다양하게 활용할 수 있을 것으로 예상된다. 초고압 균질 가공기술은 식품 폐기물인 비지에 함유된 영양성분을 효율 적으로 활용하여 가공식품을 개발하기 위한 유력한 방법인
것으로 판단된다.

\section{요 약}

본 연구는 산업 폐기물인 비지를 활용하여 부가 가치가 높은 가공식품을 개발하기 위한 일환으로 수행되었다. 즉 대두 가공 부산물인 비지를 활용하여 죽류, 음료류 및 유동 식 등의 제품으로 개발하기 위해, 초고압균질 가공 기술을 활용하여 초미세 비지 현탁액을 제조하고 추출수율, 영양 성분 및 항산화성을 확인하였다. 비지 분산액을 homogenizer 를 이용하여 $1,0000 \mathrm{rpm}$ 에서 5 분 분쇄한 후 $1,000 \mathrm{bar}$, $1,500 \mathrm{bar}$ 및 $2,000 \mathrm{bar}$ 의 압력을 가해 고압균질 가공 처리 하였다. 고압균질 가공처리한 모든 실험구가 대조군에 비 하여 추출수율이 유의적으로 증가하였다 $(\mathrm{p}<0.05)$. 초고압 균질 처리 후 총당, 환원당 및 가용성 식이섬유의 함량은 유의적으로 증가하였으며, 불용성 식이섬유는 유의적으로 감소하였다 $(\mathrm{p}<0.05)$. 단백질 함량과 유리아미노산 함량은 대조군보다 높은 경향을 나타내었다. 총 폴리페놀 함량은 처리 압력이 높아질수록 유의적으로 증가하였으며, ABTS 라디칼 소거능도 유의적으로 증대되었다 $(\mathrm{p}<0.05)$. 초고압 균질 가공 기술은 비지의 영양성분과 항산화성을 증가시키 는 매우 효과적인 가공방법이며, 비지의 영양성분을 효율적 으로 활용하여 가공식품을 제조할 수 있음을 확인하였다.

\section{References}

1. Woo EY, Kim MJ, Shin WS, Lee KA, Kim KS (2001) Production of protein hydrolyzate, that can be used as food additives, from Okara. Korean J Food Sci Technol, 33, 1769-773

2. Van der Reit WB, Wight AW, Clillierers KR, Datel JM (1989) Food chemical investigation of Tofu and its by product Okara. Food Chem, 34, 193-202

3. Hackler LR, Stillings BR, Ploimeni RJ Jr (1967) Correlation of amino acid indexes with nutritional quality of several soybean fraction. Cereal Chem, 44, 638-644

4. Lee WJ, Choi MR, Sosulski FW (1992) Separation of tofu-residue (biji) into dietary fiber and protein fractions. Korean J Food Sci Technol, 24, 97-100

5. Hackler LR, Hand DB, Steinkraus KH, Van Buren JP (1963) A comparison of the nutritional value of protein from several soybean fractions. J Nutr, 80, 205-210

6. Chung SS, Chang HN, Park MY. (1978) Dehydration of soybean residue by hot-air in conjunction with filter pressing. Korean J Food Sci Technol, 10, 1-7 
7. Kim DS, Seol NH, Kim HD (1996) Change in quality of soybean curd residue as affected by different drying methods. J Korean Soc Food Nutr, 25, 453-459

8. Song YC, Lee SP (2013) Evaluation in physicochemical properties of soy sauce fortified with soymilk residue (okara koji). Korean J Food Preserv, 20, 818-826

9. Youn UK, Kim YH, Kim SD (2003) Pigment and monacolin K content of beni-koji fermented with soybean curd residue. Korean J Food Preserv, 10, 360-364

10. Park DJ, Kim BK (2008) Food nanoparticles. Food Sci Industry, 41, 17-24

11. Suárez-Jacobo Á, Rüfer CE, Gervilla R, Guamis B, Roig-Sagués AX, Saldo J (2011) Influence of ultra-high pressure homogenisation on antioxidant capacity, polyphenol and vitamin content of clear apple juice. Food Chem, 127, 447-454

12. Huang $X$, Tu Z, Xiao H, Li Z, Zhang Q, Wang H, Hu Y, Zhang L (2013) Dynamic high pressure microfluidizationassisted extraction and antioxidant activities of sweet potato (Ipomoea batatas L.) leaves flavonoid. Food Bioprod Process, 91, 1-6

13. Wu L, Pang GC, Chen QS (2008) Study on spirulina cells fragmentation process by high pressure homogenizer. J Food Sci, 3, 002

14. Yu R (2012) Preparation of Chlorella vulgaris sub-micron suspension \& it's impact on lutein extractability and suspension stability. MS Thesis. Chungang University, Korea

15. Patras A, Brunton N, Da Pieve S, Butler F, Downey G (2009) Effect of thermal and high pressure processing on antioxidant activity and instrumental colour of tomato and carrot purées. Innovative Food Sci Emerging Tech, $10,16-22$

16. An EM, Lee JK, Choi YS, Kim YH, Shin HS (2014) Physicochemical properties of wheat bran in different areas prepared by a high-pressure homogenizer process. Korean J Food Sci Technol, 46, 404-409

17. AACC (2000) Approved methods of the AACC. 10th ed, American Association of Cereal Chemists, St. Paul, MN, USA

18. AOAC (1990) Official methods of analysis. 15th ed, Association of Official Analytical Chemists, Washington DC, USA

19. Prosky L, Asp N, Swizer TF, Devries J, Furda I (1988) Determination of insoluble and total dietary fiber on foods and food products, Interlaboratory study. J AOAC Int, 71, 1017-1023
20. Dubois M, Gilles KA, Hamilton JK, Rebers PA, Smith F (1956) Colorimetric method for determination of sugars and related substances. Anal Biochem, 28, 350

21. Luchsinger WW, Cornesky RA (1962) Reducing power by the dinirosalicylic acid method. Anal Biochem, 4, 346-347

22. Lowry OH, Rosenbrough NJ, Farr AL, Randall RJ (1951) Protein measurement with the Folin phenol reagent. J Biol Chem, 193, 265-275

23. Folin O, Denis W (1912) On phosphotungsticphosphomolybdic compounds as color reagents. J Biol Chem, 12, 239-243

24. Gutfiger T (1981) Polyphenolsoils. J Am Oil Chem Soc, 58, 966-968

25. Blois MS (1958) Antioxidant determinations by the use of a stable free radical. Nature, 4617, 1199-1200

26. Lee MS, Kim KH, Lee GJ (1987) Microbiological studies and biochemical changes in fermenting soybean curd residue during fermentation. Korean J Food Sci Technol, 19, 520-527

27. Im SK, Yoo SM, Kim TY, Chun HK (2004) Quality characteristics of bijijang in different fermentation conditions. Korean J Food Sci Technol, 36, 448-455

28. Jeong MH, Choi WY, Seo YC, Kang HY, Choi GP, Lee HY (2010) Anticancer activity of Acer mono wood extracted by ultra high pressure extraction process. Korean J Medi Crop Sci, 18, 157-167

29. Zhang S, Zhu J, Wang C (2004) Novel high pressure extraction technology. Int J Pharm, 278, 471-474

30. Chen RZ, Zhang SQ, Liu ZQ (2007) Application of ultrahigh pressure technology in extracting active component from Chinese materia medica. Chinese Tradit Herbal Drugs, 38, 1905

31. Chou SY, Chien PL, Chau CF (2008) Particle size reduction effectively enhances the cholesterol-lowering activities of carrot insoluble fiber and cellulose. J Agr Food Chem, 56, 10994-10998

32. Kim CH, Kwon MC, Syed AQ, Hwang B, Nam JH, Lee HY (2007) Toxicity reduction and improvement of anticancer activities from Rhodiola sachalinensis A. Bor by ultra high pressure extracts process. Korean J Medicinal Crop Sci, 15, 411-416

33. Lee GJ, Choi SD (2008) Application of biological industry using high hydrostatic pressure (HHP) system. Korean J Biotechnol Bioeng, 23, 362-368 